\title{
Bioinformatic Analysis of Potential Pathogenicity Effectors of Candidatus Liberibacter asiaticus, Causal Agent of Citrus Huanglongbing
}

\author{
Felipe Roberto Flores-de la Rosa* (i), Cynthia Guadalupe Rodríguez-Quibrera, \\ Cristian Matilde-Hernández, Ricardo Santillán-Mendoza*
}

Campo Experimental Ixtacuaco, Instituto Nacional de Investigaciones Forestales, Agrícolas y Pecuarias (INIFAP), Km 4.5 Carretera Federal Martínez de la Torre-Tlapacoyan, Tlapacoyan, Veracruz, México

Email: ^flores.felipe@inifap.gob.mx, *santillan.ricardo@inifap.gob.mx

How to cite this paper: Flores-de la Rosa, F.R., Rodríguez-Quibrera, C.G., MatildeHernández, C. and Santillán-Mendoza, R. (2020) Bioinformatic Analysis of Potential Pathogenicity Effectors of Candidatus Liberibacter asiaticus, Causal Agent of Citrus Huanglongbing. American Journal of Plant Sciences, 11, 1319-1330.

https://doi.org/10.4236/ajps.2020.118094

Received: July 10, 2020

Accepted: August 22, 2020

Published: August 25, 2020

Copyright $\odot 2020$ by author(s) and Scientific Research Publishing Inc. This work is licensed under the Creative Commons Attribution International License (CC BY 4.0).

http://creativecommons.org/licenses/by/4.0/ (c) (i) Open Access

\begin{abstract}
Huanglongbing (HLB) or citrus greening is currently the most important citrus disease, caused by the bacterium Candidatus Liberibacter asiaticus (CLas). The impossibility of isolating it causes understanding its pathogenic mechanisms to be a complicated task. Recent studies identified 16 proteins with the signal peptide needed to be secreted in the plant and cause the disease. The present study aims to perform a bioinformatic analysis of these proteins with the function prediction approach by gene ontology $(\mathrm{GO})$ and the detection of conserved domains. It was observed that of the 16 proteins analyzed not all are found in different infective strains reported in the literature. The GO analysis allowed us to relate different proteins with the biological process of energy and pathogenic activity, especially CLIBASIA_03315 and CLIBASIA_05115, respectively. The domain analysis allowed the observation of a $\beta$-CA domain, tentatively related to the damage caused to the chloroplast and a PAAR domain associated with the T6SS secretory system. Our results provide information on the possible function of potential pathogenicity effectors in CLas.
\end{abstract}

\section{Keywords}

Effectors, Proteins, Function Prediction, Gen Ontology, Domains, Citrus Greening

\section{Introduction}

Currently, the world citrus industry faces one of its greatest challenges in history, the HLB [1]. In Mexico, this disease is caused by the bacterium Candidatus 
Liberibacter asiaticus (CLas) [2], pathogen forced to the phloem of citrus [3] and different systems of the vector psyllid Diaphorina citri [4]. Due to the above, to date it has been impossible to obtain $C$ as axenic cultures [5] [6] which make it impossible to perform virulence, pathogenicity tests as well as Koch's postulates, to confirm the role of the bacteria in the etiology of the disease [7].

Given the importance of knowing the mechanisms by which CLas causes the disease, the complete genome of the pathogen has been obtained [8] [9]. This has allowed the study and characterization of various genetic elements of $C$ Las through bioinformatics and experimental tools [10]. Great advances have been made in the understanding of the molecular interaction between CLas and the plant, for example, the presence of a functional ATP translocase enzyme was observed in the genome of the pathogen, which suggests that one of the mechanisms used by CLas is the parasitism of energy from the plant [11]. Moreover, it has been observed that some pathogenic effectors as Las5315 induces an extreme accumulation of starch in the plant, increment the intracellular $\mathrm{H}_{2} \mathrm{O}_{2}$ content and suppress the expression of antioxidant genes [12] [13]. Likewise, the presence of structures of secretory systems in the bacteria has also been observed [12], which indicates that the use of virulence proteins is highly related to the activation of symptoms in the plant [13].

Virulence proteins or pathogenicity effectors play a transcendental role in the plant pathogen interaction according to the zigzag model [14], as these are responsible for breaking the resistance acquired by the host, as well as be targets for the activation of plant resistance [15]. In the case of phytopathogenic bacteria, effectors are released through the Type III Secretory System [16] [17] however, in the case of CLas, the structures that make up this system are absent, while the elements of the general secretion pathway (GSP/Sectranslocon) are complete [8], numerous potential proteins with the signal peptide required for their secretion have also been detected in the CLas genome [18], even some of them have been evaluated by transient expression in model plants and the characteristic symptoms of the disease have been observed [19], however, most of these proteins are still without knowledge of its function in the interaction between the plant and the pathogen.

Predicting the function of unknown proteins is one of the main current objectives of bioinformatics. One of the most commonly used approaches for the prediction of protein function is the Gene Ontology (GO), which consists in the systematization of three ontologies: 1) the biological process to which the protein is related, 2) the cellular component where the protein is located and 3) the molecular function of the protein [20] [21]. Therefore, the objective of this work was to perform, through bioinformatic tools, an analysis of the gene ontology of CLas proteins that are potential pathogenicity effectors.

\section{Materials and Methods}

\subsection{Potential Pathogenicity Effectors}

The genes reported by Pitino et al. [19] selected from Candidatus Liberibacter 
asiaticus strain Psy62 [8] based on the following criteria: 1) presence of a signal peptide in its structure, 2) length less than 250 amino acids and 3) no existing a characterization of the function in NCBI. The presence of copies of these genes was determined in the genomes of Gxpsy strain [22], ishi-1 strain [23], A4 strain [24] and FL17 strain [9] through BLAST on the NCBI platform.

\subsection{Determination of Gene Ontology}

In order to predict the possible function of the proteins of the aforementioned genes, the gene ontology (GO) approach was used [20] and the ontologies related to the Biological Process (BP), Cellular Component (CC), and Molecular Function (MF) were determined. To carry out the search, an approach based on the affinity propagation and the architecture of the domains in the amino acid sequences was used, using the PANDA online software

(http://dna.cs.miami.edu/PANDA/) [25], with the options offered by default. The results were consulted with the Quick GO database

(https://www.ebi.ac.uk/QuickGO/term/GO:0016020) of the European Bioinformatics Institute (EMBL-EBI).

\subsection{Search for Conserved Domains and Protein Structure}

The presence of functional domains was determined in the different sequences of the genes under study. For this, the online MOTIF search software

(https://www.genome.jp/tools/motif/) was used to search the database of Preserved Domains (CDD) of the NCBI, for which the offered options were used. In the case that more than one domain was identified, those not related to prokaryotes were discarded and special attention was focused on those that could show virulence relationship in other organisms. The possible structure of the proteins with potential pathogenic activity coming from the bacteria was determined, for this the software Phyre2 (Protein Homology/analogY Recognition Engine V 2.0) was used [26] and the results were visualized in the software EzMol 1.22 (http://www.sbg.bio.ic.ac.uk/ ezmol/). Given the experimental importance of the CLIBASIA_05315 proteins [19], a BLAST of the detected domain was performed and a multiple alignment was generated with the obtained sequences, using the Muscle algorithm; a dendrogram based on genetic distance UPGMA was also built in the MEGA X software [27]. The alignment was analyzed for conservation by specific sites using the Jalview software [28].

\section{Results and Discussion}

The sixteen proteins identified as potential pathogenicity effectors by Pitinio et al. [19] were analyzed to determine their possible role in the interaction that causes the HLB disease. From the cellular component analysis, it was observed that nine of the sixteen proteins are tentatively located in the membrane. The prediction of some proteins was very uncertain, for example, the case of CLIBASIA_02470, which only gave suggestions to localize in membrane, however, no data of biological process or relevant molecular function was obtained. 
Some of the proteins were related to biological processes associated with cellular energy (CLIBASIA_05315, CLIBASIA_00460 and CLIBASIA_03695), which is of great interest because it is considered that energy parasitism is essential in the HLB process [11]. The results of gene ontology are summarized in Table 1.

The CLIBASIA_00460 protein is related to the electron transfer capacity (Table 1) and is present in all the genomes of Clas analyzed (Table 2), so it is very interesting that in the domain analysis a conserved domain PAAR is located (proline-alanine-alanine-arginine) which has been observed binds to the VgrG spike system as a conical extension, forming a type of contractable mechanism similar to that present in bacteriophages [29], this belongs to the secretory system type VI (T6SS) and gives it the ability to release different types of toxic molecules to the plant [30], with a high degree of efficiency and specificity [31]. The domain structure observed in our results (Figure $1(\mathrm{a})$ ) is very similar to those that have been presented in other investigations of the PAAR domain in proteins associated with T6SS [29]. These results suggest that the protein CLIBASIA_00460 may be associated with the release of effectors during the development of HLB mediated by T6SS, which has proved to be an essential part in the development process of other diseases in other crops [32], because it confers advantages in the adaptation and colonization of the hosts [33].

Table 1. Prediction of the function based on Gene Ontology of potential proteins as pathogenicity effectors of Candidatus Liberibacter asiaticus described by Pitino et al. [19].

\begin{tabular}{|c|c|c|c|c|c|c|}
\hline \multirow[b]{2}{*}{ CLIBASIA } & \multicolumn{2}{|c|}{ Biological Process } & \multicolumn{2}{|c|}{ Cell Component } & \multicolumn{2}{|c|}{ Molecular Function } \\
\hline & $\begin{array}{l}\text { Annotation } \\
\text { GO }\end{array}$ & Description & $\begin{array}{l}\text { Annotation } \\
\text { GO }\end{array}$ & Description & $\begin{array}{l}\text { Annotation } \\
\text { GO }\end{array}$ & Description \\
\hline 05315 & 0019402 & Metabolic process of galactitol & 0005886 & Plasma membrane & 046961 & $\begin{array}{l}\text { Proton transport and } \\
\text { ATPase activity }\end{array}$ \\
\hline 05320 & 0051782 & Negative regulation of cell division & 0009276 & Cell wall Gram negative & - & - \\
\hline 00460 & 0045454 & Homeostasis redox celular & 0005623 & Cell & 0009055 & Electron transfer \\
\hline 00525 & 0006457 & Protein folding & 0016272 & Prefoldin complex & 0051082 & Protein links \\
\hline 00530 & 0009082 & $\begin{array}{l}\text { Biosynthesis of branched chains of } \\
\text { amino acids }\end{array}$ & 0016021 & $\begin{array}{l}\text { Integral component of } \\
\text { the membrane }\end{array}$ & - & - \\
\hline 02215 & 0010603 & $\begin{array}{l}\text { Regulation of mRNA in the } \\
\text { cytoplasm }\end{array}$ & 0010494 & $\begin{array}{l}\text { Cytoplasmic stress } \\
\text { granules }\end{array}$ & 0042834 & Peptidoglycan binding \\
\hline 02470 & 0008150 & Biological process & 0016020 & Membrane & 0008408 & Activity 3'-5' exonuclease \\
\hline 03230 & 0006974 & Cellular response to DNA damage & 0016020 & Membrane & 0042834 & Peptidoglycan binding \\
\hline 03695 & 0006754 & ATP biosynthetic process & 0016020 & Membrane & 0008146 & Sulfotransferase \\
\hline 04025 & 0055114 & Oxido-reduction process & 0016020 & Membrane & 0042834 & Peptidoglycan binding \\
\hline 04040 & 0009636 & Response to toxic substances & 0016021 & Membrane & 0003779 & Actin binding \\
\hline 04320 & 0009245 & Biosynthetic process of lipid A & 0043231 & Intracellular membrane & 0004565 & $\beta$-galactosidase activity \\
\hline 04330 & 0046785 & Microtubule polymerization & 0016020 & Membrane & 0015631 & Tubulin binding \\
\hline 04425 & 0016043 & Organization of cellular components & 0005623 & Cell & 0017048 & GTP catalysis \\
\hline 04560 & 0015948 & Methanogenesis & 0016020 & Membrane & 0042834 & Peptidoglycan binding \\
\hline 05115 & 0009405 & Pathogenesis & 0016020 & Membrane & 0000166 & Nucleotide binding \\
\hline
\end{tabular}


Table 2. Presence of the different genes with pathogenicity effector potential in different genomes of Candidatus Liberibacter asiaticus reported in the literature.

\begin{tabular}{|c|c|c|c|c|c|}
\hline \multirow{2}{*}{ CLIBASIA } & \multicolumn{5}{|c|}{ Candidatus Liberibacter asiaticus } \\
\hline & Psy62 ${ }^{\mathrm{a}}$ & Gxpsy $^{b}$ & Ishi-1 ${ }^{c}$ & $\mathrm{FL}_{17}^{\mathrm{d}}$ & $\mathrm{A} 4^{\mathrm{e}}$ \\
\hline 05315 & + & + & + & + & + \\
\hline 05320 & + & + & - & + & + \\
\hline 00460 & + & + & + & + & + \\
\hline 00525 & + & + & - & + & + \\
\hline 00530 & + & - & - & - & - \\
\hline 02215 & + & + & + & + & + \\
\hline 02470 & + & + & + & + & + \\
\hline 03230 & + & + & - & + & + \\
\hline 03695 & + & + & + & + & + \\
\hline 04025 & + & + & + & + & + \\
\hline 04040 & + & - & - & - & + \\
\hline 04320 & + & - & + & - & + \\
\hline 04330 & + & + & + & + & + \\
\hline 04425 & + & + & + & + & + \\
\hline 04560 & + & - & - & + & + \\
\hline 05115 & + & + & + & + & + \\
\hline
\end{tabular}

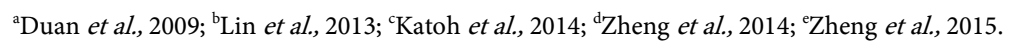

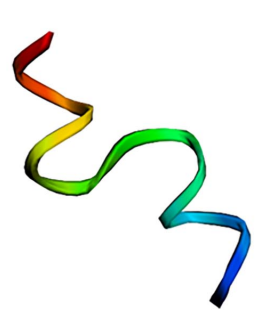

(a)

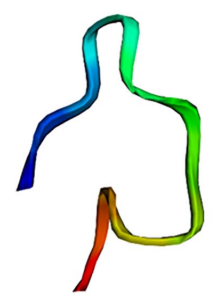

(c)

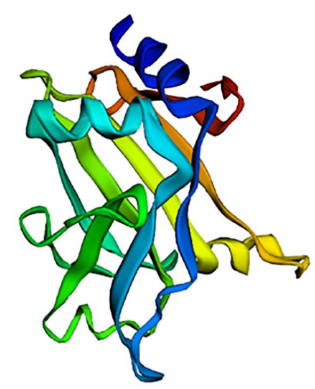

(b)

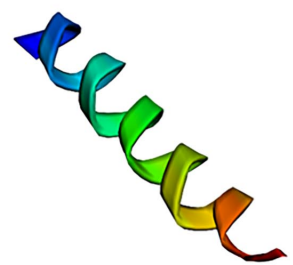

(d)

Figure 1. Speculative models of the three-dimensional structure of four proteins with potential effector activity of Candidatus Liberibacter asiaticus (a) CLIBASIA_00460, (b) CLIBASIA_05115, (c) CLIBASIA_05315 and (d) CLIBASIA_04040. 
The protein CLIBASIA_05115 is related to the biological process of pathogenesis, while membrane location and molecular function related to nucleotide binding are predicted, therefore, this protein is of future interest in the study of the interaction between CLas and the plant (Table 1), however, no conserved domains were detected (Table 2). The structural analysis of the protein showed a high degree of similarity (data not shown) with the invasive protein Bartonella baciliformis b [34], which suggests a potential role in the pathogenicity of the bacteria.

A case of special interest in the pathogenic interaction of HLB is the protein CLIBASIA_05315, which proved to be located very close to the chloroplasts when transient expression was made in Nicotiana bethamiana [19], it is also reported that it causes some of the main symptoms of HLB such as chlorosis and starch accumulation in the same model [13]. Therefore, the detection of a domain corresponding to a $\beta$ carbonic anhydrase $(\beta$-CA) is of relevant importance in the understanding of $C$ Las action mechanisms (Table 3 ).

Table 3. Conserved domains present in genes with potential pathogenicity effectors Candidatus Liberibacter asiaticus.

\begin{tabular}{|c|c|c|}
\hline CLIBASIA & $\begin{array}{l}\text { Conserved domain } \\
\text { NCBI-CDD }\end{array}$ & Description* \\
\hline 05315 & beta_CA_cladeA & $\begin{array}{l}\text { Carbonic anhydrase. Enzymes that participate in the hydration of } \\
\mathrm{CO}_{2} \text { during photosynthesis. }\end{array}$ \\
\hline 05320 & - & - \\
\hline 00460 & PAAR_1 & $\begin{array}{l}\text { Proline-alanine-alanine-arginine PAAR domain. It is part of the } \\
\text { T6SS complex forming a conical extension of the VgrG } \\
\text { mechanism. It is related to the release of toxic molecules. }\end{array}$ \\
\hline 00525 & PRK10760 & Murein hydrolase B \\
\hline 00530 & SMC_prok_A & $\begin{array}{l}\text { Chromosome segregation protein (SMC). It acts in the } \\
\text { organization and segregation of chromosomes in prokaryotes. }\end{array}$ \\
\hline 02215 & $\mathrm{FabH}$ & $\begin{array}{l}\text { 3-oxoacyl synthetase III. Related to lipid transport and } \\
\text { metabolism. }\end{array}$ \\
\hline 02470 & YecT & It belongs to the DUF1311 family. Uncharacterized function \\
\hline 03230 & $\mathrm{Na}$ _H_antiport_2 & $\begin{array}{l}\text { It belongs to the } \mathrm{Na}^{+} / \mathrm{H}^{+} \text {membrane antiport genes, present in the } \\
\text { membrane. }\end{array}$ \\
\hline 03695 & SPAN & $\begin{array}{l}\text { Surface presentation of antigenic proteins. It is related to the } \\
\text { release of virulence factors in mammals. }\end{array}$ \\
\hline 04025 & - & - \\
\hline 04040 & DUF2397 & $\begin{array}{l}\text { Domain conserved in proteins with unknown function. It has been } \\
\text { observed in a wide range of bacteria, including Ralstonia } \\
\text { solanacearum. }\end{array}$ \\
\hline 04320 & - & - \\
\hline 04330 & $\operatorname{Imm} 45$ & $\begin{array}{l}\text { Proteins that present this domain are part of the polymorphic } \\
\text { systems of toxins in bacteria. }\end{array}$ \\
\hline 04425 & DUF4456 & Domain of unknown function. \\
\hline 04560 & PTKc_ALK_LTK & Catalytic activity \\
\hline 05115 & - & - \\
\hline
\end{tabular}

${ }^{\star}$ Information obtained from https://www.genome.jp/tools/motif/. 
The $\beta$-CA enzymes are part of various processes in cells, including respiration and photosynthesis, mediating the reversible reaction of $\mathrm{CO}_{2}-\mathrm{HCO}_{3}$ [35]. However, it has been observed that these enzymes are related to many other physiological processes such as $\mathrm{CO}_{2}$ fixation, lipid and amino acid biosynthesis, establishment of seedlings and response to stress [36]. The understanding of the role of these enzymes in the activation of resistance to diseases is not yet well understood, however, experimental evidence suggests that they actively participate as a salicylic acid receptor [37], and generate activation of Acquired Systemic Resistance (SAR) [38]; therefore, it is considered that the role of $\beta$-CA is related to a protection against oxidative stress in the plant [39].

Recent studies indicate that the accumulation of ATP and $\mathrm{H}_{2} \mathrm{O}_{2}$ in plants infected with HLB is due to a significant increase in the biosynthesis activity of oxidizing compounds related to the protection of the plant and a decrease in the detoxifying elements of the same, for which reason, CLas generates an oxidative stress that damages the cells of the plant [40], damage in which the protein CLIBASIA_05315 seems to be intricately involved [13]. The fact that said protein contains a domain related to $\beta$-CA suggests that its role in the activation of the disease is that of pathogenicity effector [14] since it somehow breaks the activity of $\beta$-CA present in the chloroplast, altering its photosynthetic activity, causing the accumulation of oxidizing compounds and inhibiting their role in the activation of SAR.

Previously, the presence of $\beta$-CA in different pathogenic bacteria has been detected [41], especially in human pathogens [42] [43]. Additionally, the presence of these enzymes has been observed in pests and pathogens of agricultural importance, for which it represents a possible objective in the development of chemical control strategies [44]. However, the analysis of conservation (Figure 2) and genetic differentiation (Figure 3) clearly show that the domain found in the protein CLIBASIA_05315 is different from that found in other bacteria,

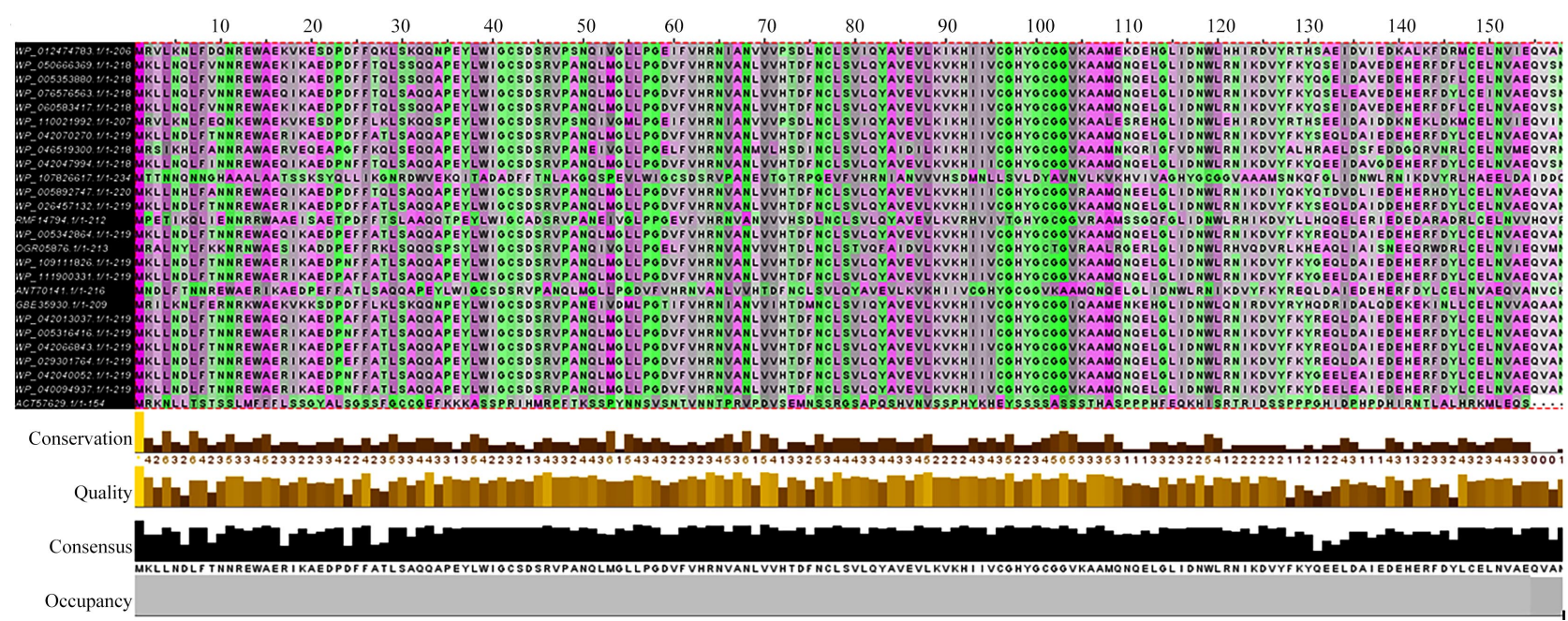

Figure 2. Conservation analysis of each position in the multiple alignment of the $\beta$-CA domain found in the protein CLIBASIA_05315 (last row). A high variation in the amino acid sequence is clearly observed compared to the bacteria to which it is compared by BLAST. 


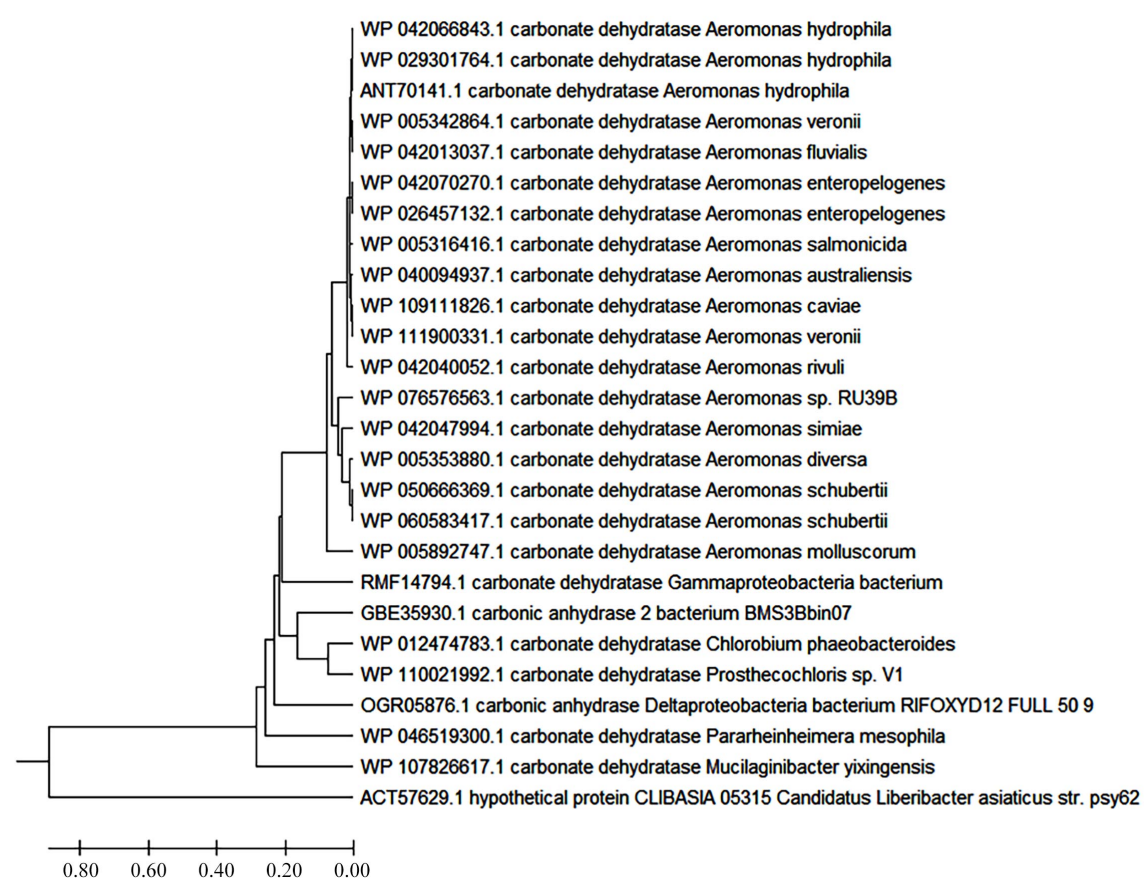

Figure 3. UPGMA analysis of the $\beta$-CA domain from the protein CLIBASIA_05315 and different bacteria related by BLASTp.

therefore, experimental evidence of the presence of the $\beta$-CA domain in the protein CLIBASIA_05315 is necessary, because this could help to understand more fully the mechanisms by which pathogenicity develops in plants with HLB, as well as develop possible mechanisms to control the disease.

In conclusion, the analysis of gene ontology (GO) allowed us to observe that of the sixteen proteins proposed by Pitino et al. [19], some are tentatively associated with cellular energy, membranes and electron transfer. The detected domains suggest that the presence of $\beta$-CA in CLIBASIA_05315 is related to its affinity to the chloroplast and the physiological alteration previously demonstrated. In turn, the PAAR domain in the protein CLIBASIA_05115 suggests the active participation of T6SS during the development of HLB.

Our findings allow us to direct the future research to the study of effectors of the Candidatus Liberibacter asiaticus in plants as a pathogenicity marker and as a molecular blank for development of diseases control strategies.

\section{Acknowledgements}

The research was supported by a grant from Fideicomiso-INIFAP of the Instituto Nacional de Investigaciones Forestales, Agrícolas y Pecuarias (SIGI 2-1.61210034811-A-M.2-3).

\section{Conflicts of Interest}

The authors declare that the research was conducted in the absence of any commercial or financial relationships that could be construed as a potential conflict of interest. 


\section{References}

[1] McCollum, G. and Baldwin, E. (2016) Huanglongbing: Devastating Disease of Citrus. Horticultural Reviews, 44, 315-361. https://doi.org/10.1002/9781119281269.ch7

[2] Flores-Sánchez, J.L., Aguilera, G.M., Loeza-Kuk, E., López-Arroyo J.I., DomínguezMonge, S., Acevedo-Sánchez, G. and Robles-García, P. (2015) Pérdidas en Producción inducidas por Candidatus Liberibacter asiaticus en Limón Persa, en Yucatán México. Mexican Journal of Phytopathology, 33, 195-210.

[3] Ding, F., Duan, Y., Paul, C., Brlansky, R.H. and Hartung, J.S. (2015) Localization and Distribution of "Candidatus Liberibacter asiaticus" in Citrus and Periwinkle by Direct Tissue Blot Immuno Assay with an Anti-Ompa Polyclonal Antibody. PLoS ONE, 10, e0123939. https://doi.org/10.1371/journal.pone.0123939

[4] Ghanim, M., Achor, D., Ghosh, S., Kontsedalov, S., Lebedev, G. and Levy, A. (2017) "Candidatus Liberibacter asiaticus" Accumulates inside Endoplasmic Reticulum Associated Vacuoles in the Gut Cells of Diaphorina citri. Scientific Reports, 7, Article No. 16945. https://doi.org/10.1038/s41598-017-16095-w

[5] Davis, M.J. and Brlansky, R. (2007) Culturing Fastidious Prokaryotes-Points to Consider When Working with Citrus Huanglongbing or Greening. Proceedings of the Florida State Horticultural Society, 120, 136-137.

[6] Jain, M., Munoz-Bodnar, A. and Gabriel, D.W. (2017) Concomitant Loss of the Glyoxalase System and Glycolysis Makes the Uncultured Pathogen "Candidatus Liberibacter asiaticus" an Energy Scavenger. Applied and Environmental Microbiology, 83, e01670-17. https://doi.org/10.1128/AEM.01670-17

[7] Chen, J., Deng, X., Civerolo, E.L., Lee, R.F., Jones, J.B., Zhou, C., Hartung, J.S., Manjunath, K.L. and Brlansky, R.H. (2011) "Candidatus Liberibacter Species": Without Koch's Postulates Completed, Can the Bacterium Be Considered as the Causal Agent of Citrus Huanglongbing (Yellow Shoot Disease)? Acta Phytopathologica Sinica, 41, 113-117.

[8] Duan, Y., Zhou, L., Hall, D.G., Li, W., Doddapaneni, H., Lin, H., Liu, L., Vahling, C.M., Gabriel, D.W., Williams, K.P., Dickerman, A., Sun, Y. and Gottwald, T. (2009) Complete Genome Sequence of Citrus Huanglongbing Bacterium, "Candidatus Liberibacter asiaticus" Obtained through Metagenomics. Molecular PlantMicrobe Interactions, 22, 1011-1020. https://doi.org/10.1094/MPMI-22-8-1011

[9] Zheng, Z., Sun, X., Deng, X. and Chen, J. (2015) Whole-Genome Sequence of "Candidatus Liberibacter asiaticus" from a Huanglongbing-Affected Citrus Tree in Central Florida. Genome Announcements, 3, e00169-15. https://doi.org/10.1128/genomeA.00169-15

[10] Coyle, J.F., Lorca, G.L. and Gonzalez, C.F. (2018) Understanding the Physiology of Liberibacter asiaticus. An Overview of the Demonstrated Molecular Mechanisms. Journal of Molecular Microbiology and Biotechnology, 3610, 116-127. https://doi.org/10.1159/000492386

[11] Vahling, C.M., Duan, Y. and Lin, H. (2010) Characterization of an ATP Translocase Identified in the Destructive Plant Pathogen "Candidatus Liberibacter asiaticus". Journal of Bacteriology, 192, 834-840. https://doi.org/10.1128/JB.01279-09

[12] Hao, G., Boyle, M., Zhou, L. and Duan, Y. (2013) The Intracellular Citrus Huanglongbing Bacterium, "Candidatus Liberibacter asiaticus" Encodes Two Novel Autotransporters. PLoS ONE, 8, e68921. https://doi.org/10.1371/journal.pone.0068921

[13] Pitino, M., Allen, V. and Duan, Y. (2018) Las $\Delta 5315$ Effector Induces Extreme 
Starch Accumulation and Chlorosis as Ca. Liberibacter asiaticus Infection in Nicotiana benthamiana. Frontiers in Plant Science, 9, 113. https://doi.org/10.3389/fpls.2018.00113

[14] Jones, J.D.G. and Dangl, J.L. (2006) The Plant Immune System. Nature, 444, 323-329. https://doi.org/10.1038/nature05286

[15] Silva, M.S., Arraes, F.B.M., Campos, M.A., Grossi-de-Sa, M., Fernandez, D., de Souza Cândido, E., Cardoso, M.H., Franco, O.L. and Grossi-de-Sa, M.F. (2018) Review: Potential Biotechnological Assets Related to Plant Immunity Modulation Applicable in Engineering Disease-Resistant Crops. Plant Science, 270, 72-84. https://doi.org/10.1016/j.plantsci.2018.02.013

[16] Tang, X., Xiao, Y. and Zhou, J.M. (2006) Regulation of the Type III Secretion System in Phytopathogenic Bacteria. Molecular Plant-Microbe Interactions, 19, 1159-1166. https://doi.org/10.1094/MPMI-19-1159

[17] Chang, J.H., Desveaux, D. and Creason, A.L. (2014) The ABCs and 123s of Bacterial Secretion Systems in Plant Pathogenesis. Annual Review of Phytopathology, 52, 317-345. https://doi.org/10.1146/annurev-phyto-011014-015624

[18] Prasad, S., Xu, J., Zhang, Y. and Wang, N. (2016) SEC-Translocon Dependent Extracytoplasmic Proteins of Candidatus Liberibacter asiaticus. Frontiers in Microbiology, 7, e84469. https://doi.org/10.3389/fmicb.2016.01989

[19] Pitino, M., Armstrong, C.M., Cano, L.M. and Duan, Y. (2016) Transient Expression of Candidatus Liberibacter asiaticus Effector Induces Cell Death in Nicotiana benthamiana. Frontiers in Plant Science, 7, 982. https://doi.org/10.3389/fpls.2016.00982

[20] Ashburner, M., Ball, C.A., Blake, J.A., Botstein, D., Butler, H., et al. (2000) Gene Ontology: Tool for the Unification of Biology. Nature Genetics, 25, 25-29. https://doi.org/10.1038/75556

[21] Huntley, R.P., Sawford, T., Martin, M.J. and O’Donovan, C. (2014) Understanding How and Why the Gene Ontology and Its Annotations Evolve: The GO within UniProt. Gigascience, 3, 4. https://doi.org/10.1186/2047-217X-3-4

[22] Lin, H., Han, C.S., Liu, B., Lou, B., Bai, J., Deng, C., Civerolo, E.L. and Gupta, G. (2013) Complete Genome Sequence of a Chinese Strain of "Candidatus Liberibacter asiaticus". Genome Announcements, 1, e00184-13. https://doi.org/10.1128/genomeA.00184-13

[23] Katoh, H., Miyata, S.I., Inoue, H. and Iwanami, T. (2014) Unique Features of a Japanese "Candidatus Liberibacter asiaticus" Strain Revealed by Whole Genome Sequencing. PLoS ONE, 9, e106109. https://doi.org/10.1371/journal.pone.0106109

[24] Zheng, Z., Deng, X. and Chen, J. (2014) Whole-Genome Sequence of "Candidatus Liberibacter asiaticus" from Guangdong, China. Genome Announcements, 2, e00273-14. https://doi.org/10.1128/genomeA.00273-14

[25] Wang, Z., Zhao, C., Wang, Y., Sun, Z. and Wang, N. (2018) PANDA: Protein Function Prediction Using Domain Architecture and Affinity Propagation. Scientific Reports, 8, Article No. 3484. https://doi.org/10.1038/s41598-018-21849-1

[26] Kelley, L.A., Mezulis, S., Yates, C.M., Wass, M.N. and Sternberg, M.J.E. (2015) The Phyre2 Web Portal for Protein Modeling, Prediction and Analysis. Nature Protocols, 10, 845. https://doi.org/10.1038/nprot.2015.053

[27] Kumar, S., Stecher, G., Li, M., Knyaz, C. and Tamuraet, K. (2018) MEGA X: Molecular Evolutionary Genetics Analysis across Computing Platforms. Molecular Biology and Evolution, 35, 1547-1549. https://doi.org/10.1093/molbev/msy096

[28] Waterhouse, A.M., Procter, J.B., Martin, D.M.A., Clamp, M. and Barton, G.J. (2009) 
Jalview Version 2-A Multiple Sequence Alignment Editor and Analysis Workbench. Bioinformatics, 25, 1189-1191. https://doi.org/10.1093/bioinformatics/btp033

[29] Shneider, M.M., Buth, S.A., Ho, B.T., Basler, M., Mekalanos, J.J. and Leiman, P.G. (2014) PAAR-Repeat Proteins Sharpen and Diversify the Type VI Secretion System Spike. Nature, 500, 350-353. https://doi.org/10.1038/nature12453

[30] Cianfanelli, F.R., Alcoforado, D.J., Guo, M., De Cesare, V., Trost, M. and Coulthurst, S.J. (2016) VgrG and PAAR Proteins Define Distinct Versions of a Functional Type VI Secretion System. PLoS Pathogens, 12, e1005735. https://doi.org/10.1371/journal.ppat.1005735

[31] Bondage, D.D., Lin, J.S., Ma, L.S., Kuo, C.H. and Lai, E.M. (2016) VgrG C Terminus Confers the Type VI Effector Transport Specificity and Is Required for Binding with PAAR and Adaptor-Effector Complex. Proceedings of the National Academy of Sciences, 113, E3931-E3940. https://doi.org/10.1073/pnas.1600428113

[32] Kamber, T., Pothier, J.F., Pelludat, C., Rezzonico, F., Duffy, B. and Duffy, T.H.M. (2017) Role of the Type VI Secretion Systems during Disease Interactions of Erwinia amylovora with Its Plant Host. BMC Genomics, 18, 628. https://doi.org/10.1186/s12864-017-4010-1

[33] Bernal, P., Llamas, M.A. and Filloux, A. (2018) Type VI Secretion Systems in Plant-Associated Bacteria. Environmental Microbiology, 20, 1-15.

https://doi.org/10.1111/1462-2920.13956

[34] Coleman, S.A. and Minnick, M.F. (2001) Establishing a Direct Role for the Bartonella bacilliformis Invasion-Associated Locus B (Ia1B) Protein in Human Erythrocyte Parasitism. Infection and Immunity, 69, 4373-4381. https://doi.org/10.1128/IAI.69.7.4373-4381.2001

[35] Bhat, F.A., Ganai, B.A. and Uqab, B. (2017) Carbonic Anhydrase: Mechanism, Structure and Importance in Higher Plants. Asian Journal of Plant Science and Research, 7, 17-23.

[36] DiMario, R.J., Clayton, H., Mukherjee, A., Ludwig, M. and Moroney, J.V. (2017) Plant Carbonic Anhydrases: Structures, Locations, Evolution, and Physiological Roles. Molecular Plant, 10, 30-46. https://doi.org/10.1016/j.molp.2016.09.001

[37] Medina-Puche, L., Castelló, M.J., Canet, J.V., Lamilla, J., Colombo, L. and Tornero, P. (2017) $\beta$-Carbonic Anhydrases Play a Role in Salicylic Acid Perception in Arabidopsis. PLoS ONE, 12, e0181820. https://doi.org/10.1371/journal.pone.0181820

[38] Klessig, D.F., Choi, H.W. and Dempsey, D.A. (2018) Systemic Acquired Resistance and Salicylic Acid: Past, Present, and Future. Molecular Plant-Microbe Interactions, 31, 871-888. https://doi.org/10.1094/MPMI-03-18-0067-CR

[39] Floryszak-Wieczorek, J. and Arasimowicz-Jelonek, M. (2017) The Multifunctional Face of Plant Carbonic Anhydrase. Plant Physiology and Biochemistry, 112, 362-368. https://doi.org/10.1016/j.plaphy.2017.01.007

[40] Pitino, M., Armstrong, C.M. and Duan, Y. (2017) Molecular Mechanisms behind the Accumulation of ATP and $\mathrm{H}_{2} \mathrm{O}_{2}$ in Citrus Plants in Response to "Candidatus Liberibacter asiaticus” Infection. Horticulture Research, 4, Article No. 17040. https://doi.org/10.1038/hortres.2017.40

[41] Supuran, C.T. and Capasso, C. (2017) An Overview of the Bacterial Carbonic Anhydrases. Metabolites, 7, 56. https://doi.org/10.3390/metabo7040056

[42] Tobal, J.M. and da Silva Ferreira Balieiro, M.E. (2013) Role of Carbonic Anhydrases in Pathogenic Microorganisms: A Focus on Aspergillus fumigatus. Journal of Medical Microbiology, 63, 15-27. https://doi.org/10.1099/jmm.0.064444-0

[43] Stefanucci, A., Angeli, A., Dimmito, M.P., Luisi, G., Del Prete, S., Capasso, C., Do- 
nald, W.A., Mollica, A. and Supuran, C.T. (2018) Activation of $\beta$ - and $\gamma$-Carbonic Anhydrases from Pathogenic Bacteria with Tripeptides. Journal of Enzyme Inhibition and Medicinal Chemistry, 33, 945-950.

https://doi.org/10.1080/14756366.2018.1468530

[44] Emameh, Z.R., Barker, H., Hytönen, V.P., Tolvanen, M.E.E. and Parkkila, S. (2014) Beta Carbonic Anhydrases: Novel Targets for Pesticides and Anti-Parasitic Agents in Agriculture and Livestock Husbandry. Parasites and Vectors, 7, 403.

https://doi.org/10.1186/1756-3305-7-403 